\title{
Film-mulched continuous ridge-furrow planting improves soil temperature, nutrient content and enzymatic activity in a winter oilseed rape field, Northwest China
}

\author{
GU Xiaobo, LI Yuannong*, DU Yadan
}

Key Laboratory of Agricultural Soil and Water Engineering in Arid and Semiarid Areas of Ministry of Education, Northwest A\&F University, Yangling 712100, China

\begin{abstract}
Film mulching system is a widely employed agricultural practice worldwide. However, the effects of different planting and mulching patterns on soil nutrient content and enzymatic activity have not been well documented. In this study, we examined the impact of four planting and mulching patterns (including control, flat planting without mulching; M1, flat planting with film mulching; M2, ridge-furrow planting with film mulching on both ridges and furrows; and M3, ridge-furrow planting with film mulching on continuous ridges) on the seed yield of winter oilseed rape, soil moisture, soil temperature, soil organic carbon (SOC) content, soil nutrient content, and soil enzymatic activity over three growing seasons from 2012 to 2015 in a winter oilseed rape field in the semi-arid area of Northwest China. Seed yield of winter oilseed rape, soil moisture, soil temperature, enzymatic activities, and contents of nitrate-nitrogen, available phosphorus, and available potassium were all significantly higher in mulching treatments (M1, M2 and M3) than in control treatment over the three growing seasons, whereas SOC content was significantly lower in mulching treatments than in control treatment during 2013-2014 and 2014-2015. Among the three mulching treatments (M1, M2 and M3), the M3 treatment showed consistently higher seed yield, SOC content, nutrient contents, and enzymatic activities than the other two treatments. Seed yield of winter oilseed rape was $41.1 \%$ and $15.0 \%$ higher in M3 than in M1 and M2, respectively. SOC content and soil enzymatic activities in the top $0-20 \mathrm{~cm}$ soil layers and nitrate-nitrogen content in the top 0-30 cm soil layers were all significantly higher in M3 than in M1 and M2. Therefore, we advise the ridge-furrow planting with film mulching on continuous ridges (i.e., M3) as an efficient planting and mulching pattern for sustainably improving the seed yield of winter oilseed rape and preserving soil fertility in the semi-arid area of Northwest China.
\end{abstract}

Keywords: film mulching; soil temperature; soil organic carbon; soil nutrient content; soil enzymatic activity; winter oilseed rape; Northwest China

Citation: GU Xiaobo, LI Yuannong, DU Yadan. 2018. Film-mulched continuous ridge-furrow planting improves soil temperature, nutrient content and enzymatic activity in a winter oilseed rape field, Northwest China. Journal of Arid Land, 10(3): 362-374. https://doi.org/10.1007/s40333-018-0055-5

\section{Introduction}

China is one of the world's most populous and fastest-developing countries where the

\footnotetext{
*Corresponding author: LI Yuannong (E-mail: liyuannong@163.com)

Received 2017-08-04; revised 2017-12-08; accepted 2018-01-04

C Xinjiang Institute of Ecology and Geography, Chinese Academy of Sciences, Science Press and Springer-Verlag GmbH Germany, part of Springer Nature 2018
} 
development of sustainable agriculture is necessary for continued growth. Currently, China's agriculture is hampered by the scarcity of water resources due to considerable demands in domestic, industrial, and municipal commerce, especially in arid and semi-arid regions of Northwest China (Huang, 2014). Water demands are high in arid and semi-arid regions of Northwest China where the maintenance of sustainable agricultural development is mostly limited by water scarcity (Cai and Ringler, 2007; Qin et al., 2014). Adding to this problem is the relatively low efficiency of agricultural water use in arid and semi-arid regions of Northwest China (Dalin et al., 2015). In response to these issues, it is necessary to adopt new management practices and modify existing water conservation practices to improve water use efficiency and agricultural productivity in these regions.

One effective method employed to increase crop productivity in arid and semi-arid planting zones is the ridge-furrow rainwater harvesting (RFRH) system. This system utilizes plastic-covered ridges as the runoff area and furrows (covered or un-covered) as the infiltration or planting area (Tian et al., 2003). The harvesting efficiency of rainwater has been shown to reach approximately $87 \%$ under the RFRH system because of its high utilization of light rains $(<5 \mathrm{~mm})$ (Li et al., 2000). The positive impacts of the RFRH system, including more efficient use of harvested water and high increase of crop production, are well understood for maize (Wang et al., 2009), potato (Qin et al., 2014), and oilseed rape (Gu et al., 2017). There are several benefits of using the RFRH system, including extreme simplicity, cost-effectivity, high efficiency and strong adaptability. Generally speaking, the fully-mulched ridge-furrow cropping system can effectively improve soil moisture, extend moisture availability period and increase topsoil temperature (Gan et al., 2013). Despite all this, it may also influence the soil quality due to increases in soil moisture and temperature.

Soil organic carbon (SOC) is a good indicator of soil quality and productivity because of its favorable effects on the physical, chemical, and biological properties of soil (Karami et al., 2012). Previous studies have found that film mulching can decrease SOC, however, the decrease of SOC can be minimized at a certain mulching period (Li et al., 2004). Soil enzymatic activities are important in all biochemical processes in the soil environment and are closely associated with nutrient cycling, energy transfer, and environmental quality (Yao et al., 2006; Jiao et al., 2011; Kussainova et al., 2013). It has been found that the higher soil moisture that occurs under film mulching could promote soil enzyme activity and enhance SOC decomposition (Wang et al., 2016). Film mulching has been shown to improve soil nutrient content, such as total and available nitrogen $(\mathrm{N})$, phosphorus $(\mathrm{P})$ and potassium $(\mathrm{K})$ (Zhou et al., 2016). Unfortunately, no consensus has yet been reached regarding the variations of soil nutrients under film mulching. For example, Kou et al. (2011) reported that the contents of available $\mathrm{P}$ and $\mathrm{K}$ decreased under film mulching. To sum up, it is of great significance to study whether and how film mulching influences SOC, soil enzyme activities and soil nutrients.

In this study, we analyzed the influences of different planting and mulching patterns on soil qualities in a winter oilseed rape field, Northwest China. Our specific objectives were to assess the impacts of different planting and mulching patterns on SOC content, soil nutrients and soil enzyme activities, and to identify an appropriate planting and mulching pattern to sustainably improve seed yield of winter oilseed rape and maintain soil fertility.

\section{Materials and methods}

\subsection{Experimental site}

Winter oilseed rape was planted in September for three continuous growing seasons (2012-2013, 2013-2014 and 2014-2015) in the experimental site at Northwest A\&F University $\left(34^{\circ} 18^{\prime} \mathrm{N}\right.$, $108^{\circ} 24^{\prime} \mathrm{E}$; $521 \mathrm{~m}$ a.s.1.), Yangling, Shaanxi Province, China. The average annual precipitation and pan evaporation are approximately 632 and $1500 \mathrm{~mm}$, respectively. The groundwater depth is higher than $8 \mathrm{~m}$. The soil texture of the experimental site is loamy soil with $25.4 \%$ sand, $44.1 \%$ silt, and $30.5 \%$ clay. Soil basic properties in the topsoil layer $(0-20 \mathrm{~cm})$ are shown in Table 1 . 
Table 1 Soil basic properties in the topsoil layer $(0-20 \mathrm{~cm}$ depth) in September for three continuous growing seasons

\begin{tabular}{ccccccc}
\hline Growing season & $\mathrm{pH}$ & $\begin{array}{c}\text { Organic matter } \\
(\mathrm{g} / \mathrm{kg})\end{array}$ & $\begin{array}{c}\text { Total N } \\
(\mathrm{g} / \mathrm{kg})\end{array}$ & $\begin{array}{c}\text { Mineral N } \\
(\mathrm{mg} / \mathrm{kg})\end{array}$ & $\begin{array}{c}\text { Available P } \\
(\mathrm{mg} / \mathrm{kg})\end{array}$ & $\begin{array}{c}\text { Available K } \\
(\mathrm{mg} / \mathrm{kg})\end{array}$ \\
\hline $2012-2013$ & 8.12 & 12.35 & 0.95 & 75.31 & 25.34 & 131.92 \\
$2013-2014$ & 8.14 & 12.78 & 0.98 & 72.54 & 24.26 & 135.32 \\
$2014-2015$ & 8.14 & 12.18 & 0.94 & 76.01 & 25.22 & 132.97 \\
\hline
\end{tabular}

\subsection{Experimental design}

We designed four independent treatments in this study, including one treatment without mulching (control; Fig. 1a), and three treatments with polyethylene film mulching (Figs. 1b-d). Specifically, the control treatment was the flat planting without mulching, and the three mulching treatments were flat planting with film mulching (M1; Fig. 1b), ridge-furrow planting with film mulching on both ridges and furrows (M2; Fig. 1c), and ridge-furrow planting with film mulching on continuous ridges (M3; Fig. 1d). In each of the three growing seasons, four replicates were planted randomly for each treatment. The plot area was $20 \mathrm{~m}^{2}(4 \mathrm{~m} \times 5 \mathrm{~m})$ each, and the distance between two plots was $1 \mathrm{~m}$.

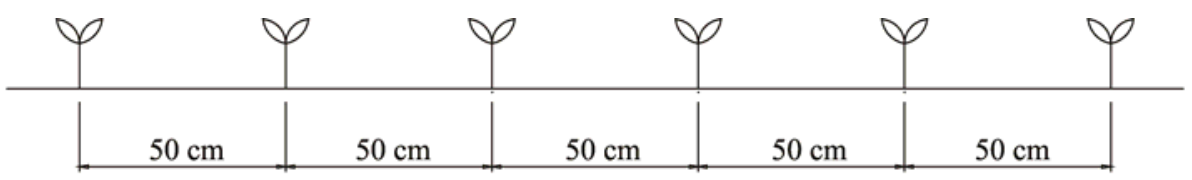

(a) Flat planting without film mulching (control)

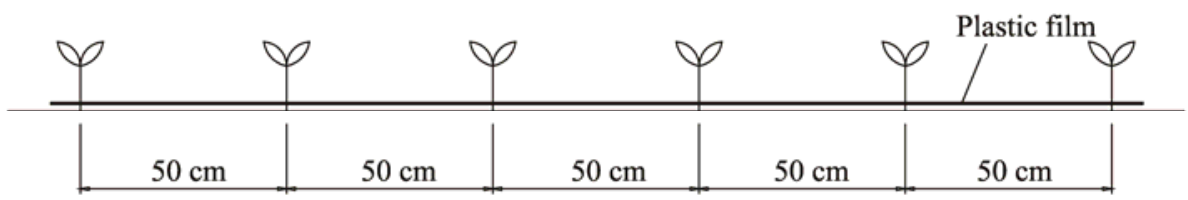

(b) Flat planting with film mulching (M1)

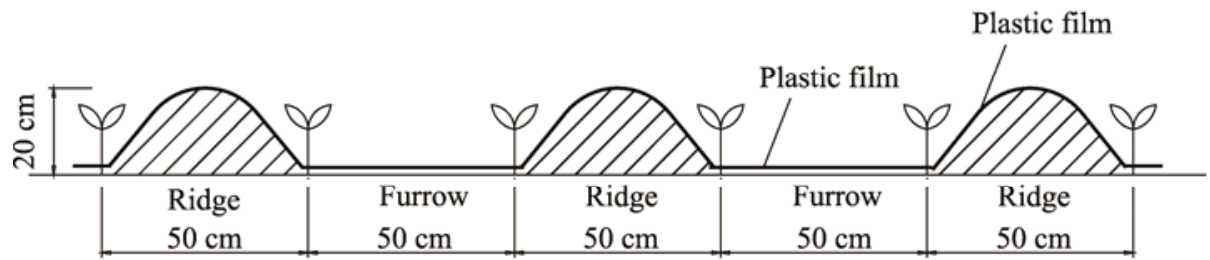

(c) Ridge-furrow planting with film mulching on both ridges and furrows (M2)

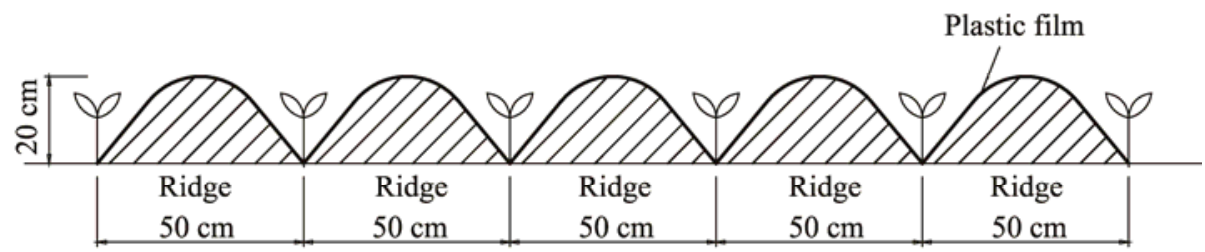

(d) Ridge-furrow planting with film mulching on continuous ridges (M3)

Fig. 1 Illustrated diagrams of the planting and mulching patterns used in this study

After ploughing, applying fertilisers, and preparing the ridge-furrows (for M2 and M3), the soil was manually covered with plastic film $(0.8 \mathrm{~m}$ wide and $0.008 \mathrm{~mm}$ thick $)$ for M1, M2 and M3. The basal fertilisers, including urea $(\mathrm{N}=46 \%)$ at $180 \mathrm{~kg} \mathrm{~N} / \mathrm{hm}^{2}$, calcium superphosphate $\left(\mathrm{P}_{2} \mathrm{O}_{5}=16 \%\right)$ at $90 \mathrm{~kg} \mathrm{P}_{2} \mathrm{O}_{5} / \mathrm{hm}^{2}$, potassium sulphate $\left(\mathrm{K}_{2} \mathrm{O}=51 \%\right)$ at $120 \mathrm{~kg} \mathrm{~K} / \mathrm{O} / \mathrm{hm}^{2}$, and borax $(\mathrm{B}=11 \%)$ at $15 \mathrm{~kg} \mathrm{~B} / \mathrm{hm}^{2}$ were applied before sowing for each treatment (control, M1, M2 and M3). Shaanyou No. 107 oilseed rape seeds were sown on 15, 12 and 21 September in 2012, 2013 
and 2014, respectively. The seedlings were thinned at the fifth-leaf stage and the density was established at $120 \times 10^{3}$ plants $/ \mathrm{hm}^{2}$. All plants were harvested in May in the three continuous growing seasons, i.e., 20 May 2013, 22 May 2014, and 23 May 2015. They were manually harvested from $1 \mathrm{~m}^{2}$ area in the center of each plot and were sun-dried and threshed to determine the seed yield.

Due to a severe drought, each plot was supplied $60 \mathrm{~mm}$ of irrigation water at 122 and 202 days after sowing during the growing season of 2012-2013. And, each plot received $30 \mathrm{~mm}$ of irrigation water after sowing in 2013-2014 to ensure seedling emergence. The volume of irrigation water was measured using a flow meter and irrigation water was transferred by a plastic pipe from a pump outlet to the plots. Field management practices were applied for each treatment, such as weeding and eliminating pests.

\subsection{Soil sampling and soil property measurements}

Soil moisture at the depth of $0-30 \mathrm{~cm}$ was determined every $15 \mathrm{~d}$ from the beginning of the stem elongation stage to the harvesting stage during each of the three growing seasons. The soil was sampled every $10 \mathrm{~cm}$ by manual coring between two plants within the same row. Soil samples were oven-dried at $105^{\circ} \mathrm{C}$ and then the average soil moisture at the $0-30 \mathrm{~cm}$ depth was calculated.

Soil temperatures at depths of 5 and $25 \mathrm{~cm}$ were measured using rectangular geothermometers (Jingda Thermal Instruments, Wuqiang County, Hebei Province, China) between two adjacent plants within the same row. Temperatures were recorded from 08:00 to 18:00 LST (at an interval of $2 \mathrm{~h}$ ) over three successive days every mid-month throughout the experimental duration. The average of six daily records was calculated to obtain the mean daily soil temperature.

Soil samples were collected at harvest each year for determining SOC content, nutrient content and enzymatic activity. Briefly, in each growing season, soil samples were obtained from the depths of $0-10,10-20$, and $20-30 \mathrm{~cm}$ using a steel-core drill at three random locations between adjacent plants in the same row within each plot. SOC content was determined using the dichromate wet oxidation method followed by titration with ferrous ammonium sulphate. Total nitrogen (TN) content was ascertained using an automatic Kjeldahl distillation-titration unit (Foss, Sweden). Total phosphorus (TP) and available phosphorus (AP) contents were determined by molybdenum-blue colorimetry using an Evolution 300 spectrophotometer (Thermo Scientific, England). It should be noted that for TP, soil samples were firstly digested with $\mathrm{H}_{2} \mathrm{SO}_{4}$ and $\mathrm{HClO}_{4}$ before measurement, and for AP, soil samples were extracted with $0.5 \mathrm{~mol} / \mathrm{L} \mathrm{NaHCO}_{3}$ at $\mathrm{pH} 8.5$ before measurement. Total potassium (TK) was detected by sodium hydroxide melting-flame photometry. Nitrate-N content was determined as described in Griffin et al. (2009). Available potassium (AK) content was obtained using the ammonium acetate extraction-flame photometry.

Invertase activity $(\mathrm{mg} /(\mathrm{g} \cdot 24 \mathrm{~h}))$, urease activity $(\mathrm{mg} /(100 \mathrm{~g} \cdot 24 \mathrm{~h}))$, and alkaline phosphatase activity $(\mathrm{mg} /(\mathrm{g} \cdot 2 \mathrm{~h}))$ were measured following the methods of Jin et al. (2009).

\subsection{Data analysis}

Analysis of variance (least significant difference test at 5\% probability) was used to test the significant differences of seed yield, soil temperature, SOC, soil nutrient content and enzymatic activity among treatments. Differences of $P<0.05$ were considered significant. Furthermore, SPSS 18.0, AutoCAD 2007 and Origin 8.5 was used for data analysis and mapping.

\section{Results}

\subsection{Meteorological conditions}

The total precipitation during the three growing seasons of 2012-2013, 2013-2014 and 2014-2015 was 120, 330 and $264 \mathrm{~mm}$, respectively (Fig. 2). Months of March-May is a key period for the reproductive growth of winter oilseed rape. The precipitation from March to May was $52 \mathrm{~mm}$ in 2012-2013, $145 \mathrm{~mm}$ in 2013-2014, and $127 \mathrm{~mm}$ in 2014-2015. A lower amount of precipitation was observed during the growing season of 2012-2013 compared with the other two growing seasons. The average precipitation during the entire growing stages of winter oilseed 
rape from 2006-2007 to 2010-2011 was $372 \mathrm{~mm}$, indicating that plants experienced severe drought during the growing season of 2012-2013.

Over the three growing seasons, similar mean daily air temperatures were observed (Fig. 2), with mean seasonal temperatures ranging from $9.2^{\circ} \mathrm{C}$ to $9.4^{\circ} \mathrm{C}$. The highest and lowest daily temperatures were $26.6^{\circ} \mathrm{C}$ and $-6.6^{\circ} \mathrm{C}, 25.6^{\circ} \mathrm{C}$ and $-4.7^{\circ} \mathrm{C}$, and $26.6^{\circ} \mathrm{C}$ and $-3.2^{\circ} \mathrm{C}$ during the growing seasons of 2012-2013, 2013-2014, and 2014-2015, respectively. The days with mean daily temperature $<0^{\circ} \mathrm{C}$ accounted for $13.6 \%$ (34 d), $14.3 \%$ (36 d) and $9.8 \%(24 \mathrm{~d})$ of the total days during the growing seasons of 2012-2013, 2013-2014 and 2014-2015, respectively.
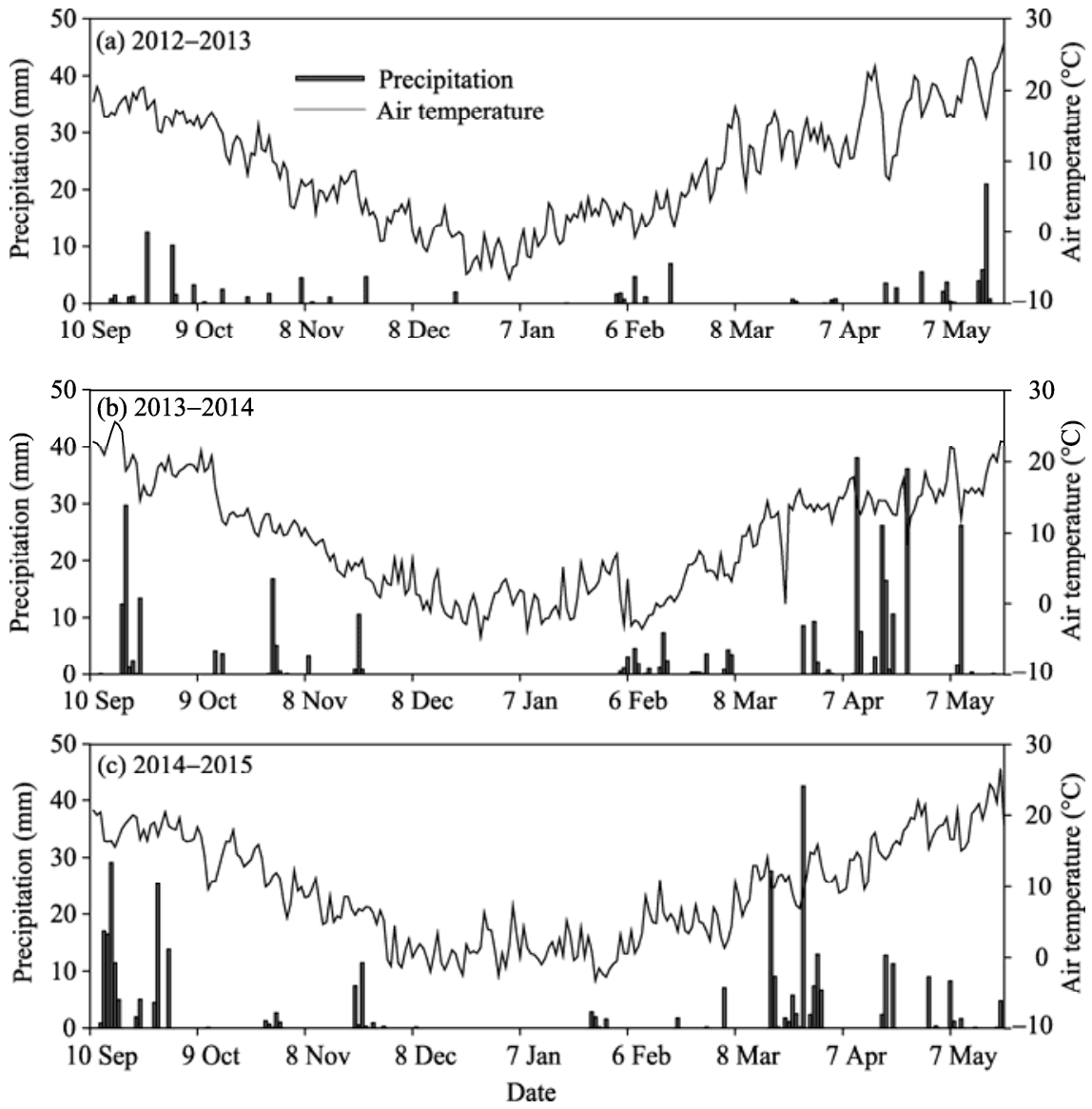

Fig. 2 Daily precipitation and mean daily air temperature during the growing seasons of 2012-2013, 2013-2014 and 2014-2015

\subsection{Seed yield}

Planting and mulching patterns significantly affected the seed yield of winter oilseed rape over the three growing seasons (Tables 2 and 3). The seed yield of winter oilseed rape was higher in M3 than in control, M1 and M2 during the whole experimental period. Specifically, the yield in M3 was $95.3 \%, 56.5 \%$ and $21.0 \%$ higher during the growing season of $2012-2013,59.7 \%, 35.0 \%$ and $11.9 \%$ higher during the growing season of $2013-2014$, and $63.0 \%, 36.3 \%$ and $13.6 \%$ higher during the growing season of 2014-2015, than those in CK, M1 and M2, respectively. Seed yield was also significantly different among the three growing seasons. The highest seed yield was found during the growing season of 2013-2014, 37.3\% and $8.9 \%$ higher than those during the growing seasons of 2012-2013 and 2014-2015, respectively.

\subsection{Soil moisture}

For all three growing seasons, soil moisture in the $0-30 \mathrm{~cm}$ soil layer was highest in $\mathrm{M} 3$ and lowest in control treatment after the stem elongation stage of winter oilseed rape (Fig. 3). At the 
beginning of the stem elongation stage, the average soil moisture in the $0-30 \mathrm{~cm}$ soil layer among the three growing seasons was $23.0 \%, 10.4 \%$ and $7.1 \%$ higher in M3 than in CK, M1 and M2, respectively. Furthermore, at the maturity stage (i.e., $75 \mathrm{~d}$ after the stem elongation stage), the average soil moisture in the $0-30 \mathrm{~cm}$ soil layer was $56.0 \%, 23.1 \%$ and $11.6 \%$ higher in $\mathrm{M} 3$ than in CK, M1 and M2, respectively.

Table 2 Seed yield of winter oilseed rape under different planting and mulching treatments during the three growing seasons

\begin{tabular}{cccc}
\hline \multirow{2}{*}{ Treatment } & & Seed yield $\left(\mathrm{kg} / \mathrm{hm}^{2}\right)$ & $2014-2015$ \\
\cline { 2 - 4 } & $2012-2013$ & $2013-2014$ & $2296^{\mathrm{d}}$ \\
\hline Control & $1646^{\mathrm{d}}$ & $2524^{\mathrm{d}}$ & $2745^{\mathrm{c}}$ \\
M1 & $2054^{\mathrm{c}}$ & $2987^{\mathrm{c}}$ & $3293^{\mathrm{b}}$ \\
M2 & $2657^{\mathrm{b}}$ & $3604^{\mathrm{b}}$ & $3742^{\mathrm{a}}$ \\
\hline
\end{tabular}

Note: Control, flat planting without mulching; M1, flat planting with film mulching; M2, ridge-furrow planting with film mulching on both ridges and furrows; M3, ridge-furrow planting with film mulching on continuous ridges. Different lowercase letters within a column denote significant differences among treatments at $P<0.05$ level.

Table 3 Analysis of variance ( $F$ value) for the seed yield of winter oilseed rape and soil properties

\begin{tabular}{|c|c|c|c|c|c|c|}
\hline $\begin{array}{c}\text { Sources of } \\
\text { variation }\end{array}$ & Seed yield & SOC & Total N & Total P & Total K & Nitrate-N \\
\hline $\begin{array}{l}\text { Planting and } \\
\text { mulching pattern } \\
\text { (M) }\end{array}$ & $176.0^{* *}$ & $6.1^{*}$ & $2.2^{\mathrm{ns}}$ & $1.8^{\mathrm{ns}}$ & $2.0^{\mathrm{ns}}$ & $7.3^{*}$ \\
\hline Planting year $(\mathrm{Y})$ & $57.7^{* *}$ & $4.1^{*}$ & $1.7^{\mathrm{ns}}$ & $1.5^{\mathrm{ns}}$ & $2.3^{\mathrm{ns}}$ & $2.1^{\mathrm{ns}}$ \\
\hline Soil depth (D) & - & $3.2^{*}$ & - & - & - & - \\
\hline $\mathrm{M} \times \mathrm{Y}$ & $89.4^{* *}$ & $3.9^{*}$ & $1.3^{\text {ns }}$ & $1.2^{\mathrm{ns}}$ & $1.8^{\mathrm{ns}}$ & $1.9^{\text {ns }}$ \\
\hline $\mathrm{M} \times \mathrm{D}$ & - & $3.0^{*}$ & - & - & - & - \\
\hline $\mathrm{D} \times \mathrm{Y}$ & - & $3.0^{*}$ & - & - & - & - \\
\hline $\mathrm{M} \times \mathrm{Y} \times \mathrm{D}$ & - & $2.7^{*}$ & - & - & - & - \\
\hline $\begin{array}{l}\text { Sources of } \\
\text { variation }\end{array}$ & Available P & Available K & $\begin{array}{c}\text { Invertase enzyme } \\
\text { activity }\end{array}$ & Urease enzyme activity & $\begin{array}{c}\text { Alkaline phosphatase } \\
\text { enzyme activity }\end{array}$ & \\
\hline $\mathrm{M}$ & $6.5^{*}$ & $8.4^{*}$ & $12.3^{* *}$ & $10.2^{* *}$ & $16.1^{* *}$ & \\
\hline $\mathrm{Y}$ & $2.3^{\text {ns }}$ & $2.1^{\mathrm{ns}}$ & $5.1^{*}$ & $3.8^{*}$ & $3.1^{*}$ & \\
\hline $\mathrm{D}$ & - & - & $19.4^{* *}$ & $16.5^{* *}$ & $14.2^{* *}$ & \\
\hline $\mathrm{M} \times \mathrm{Y}$ & $1.9^{\mathrm{ns}}$ & $1.6^{\mathrm{ns}}$ & $4.7^{*}$ & $3.4^{*}$ & $2.9^{*}$ & \\
\hline$M \times D$ & - & - & $14.7^{* *}$ & $13.6^{* *}$ & $11.8^{* *}$ & \\
\hline $\mathrm{D} \times \mathrm{Y}$ & - & - & $4.9^{*}$ & $3.7^{*}$ & $3.0^{*}$ & \\
\hline $\mathrm{M} \times \mathrm{Y} \times \mathrm{D}$ & - & - & $4.1^{*}$ & $3.0^{*}$ & $2.8^{*}$ & \\
\hline
\end{tabular}

Note: ${ }^{*}$, significance at $P<0.05$ level; ${ }^{* *}$, significance at $P<0.01$ level; ${ }^{\text {ns }}$, not significant; - , no data.
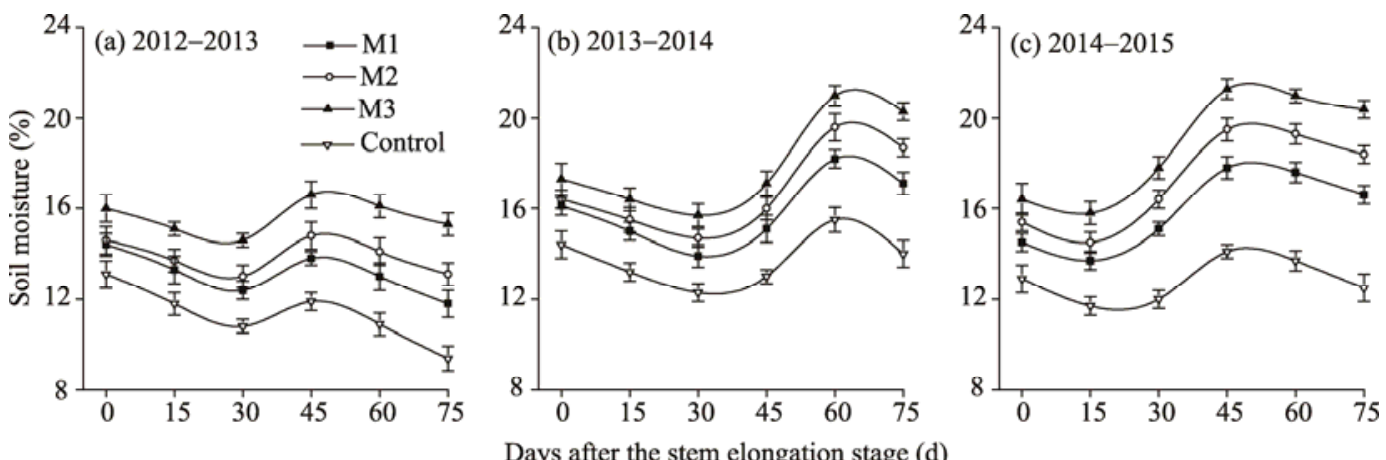

Fig. 3 Dynamics of soil moisture in the $0-30 \mathrm{~cm}$ soil layer after the stem elongation stage of winter oilseed rape under different planting and mulching treatments during the growing seasons of 2012-2013, 2013-2014 and 2014-2015. Bars represent standard deviations. Control, flat planting without mulching; M1, flat planting with film mulching; M2, ridge-furrow planting with film mulching on both ridges and furrows; M3, ridge-furrow planting with film mulching on continuous ridges. 


\subsection{Soil temperature}

During the growing season, the monthly average soil temperature at depths of 5 and $25 \mathrm{~cm}$ gradually decreased from September to December and gradually increased from January to May in all treatments (Table 4). Soil temperature variation was greater at the depth of $5 \mathrm{~cm}$ than at the depth of $25 \mathrm{~cm}$. The monthly average soil temperature in the four treatments was $0.1^{\circ} \mathrm{C}-2.3^{\circ} \mathrm{C}$ lower at the depth of $5 \mathrm{~cm}$ than at the depth of $25 \mathrm{~cm}$ in December and January, and $0.8^{\circ} \mathrm{C}-4.6^{\circ} \mathrm{C}$ higher at the depth of $5 \mathrm{~cm}$ than at the depth of $25 \mathrm{~cm}$ in other months.

Table 4 Monthly average soil temperature at depths of 5 and $25 \mathrm{~cm}$ under different planting and mulching treatments during the growing seasons of 2012-2013, 2013-2014 and 2014-2015

\begin{tabular}{|c|c|c|c|c|c|c|c|c|c|c|c|}
\hline \multirow{2}{*}{ Year } & \multirow{2}{*}{$\begin{array}{l}\text { Soil depth } \\
\quad(\mathrm{cm})\end{array}$} & \multirow{2}{*}{ Treatment } & \multicolumn{9}{|c|}{ Monthly average soil temperature $\left({ }^{\circ} \mathrm{C}\right)$} \\
\hline & & & Sep & Oct & Nov & Dec & Jan & Feb & Mar & Apr & May \\
\hline \multirow{8}{*}{$2012-2013$} & \multirow{5}{*}{5} & $\mathrm{CK}$ & $18.6^{\mathrm{b}}$ & $14.9^{\mathrm{b}}$ & $5.5^{\mathrm{b}}$ & $0.9^{\mathrm{b}}$ & $2.3^{\mathrm{b}}$ & $4.1^{\mathrm{b}}$ & $9.6^{\mathrm{b}}$ & $22.4^{\mathrm{a}}$ & $20.7^{\mathrm{a}}$ \\
\hline & & M1 & $23.0^{\mathrm{a}}$ & $18.5^{\mathrm{a}}$ & $7.9^{\mathrm{a}}$ & $2.6^{\mathrm{a}}$ & $3.9^{\mathrm{a}}$ & $6.7^{\mathrm{a}}$ & $12.0^{\mathrm{a}}$ & $23.2^{\mathrm{a}}$ & $21.2^{\mathrm{a}}$ \\
\hline & & M2 & $22.6^{\mathrm{a}}$ & $17.9^{\mathrm{a}}$ & $7.5^{\mathrm{a}}$ & $2.4^{\mathrm{a}}$ & $3.8^{\mathrm{a}}$ & $6.3^{\mathrm{a}}$ & $11.6^{\mathrm{a}}$ & $23.0^{\mathrm{a}}$ & $21.0^{\mathrm{a}}$ \\
\hline & & M3 & $22.1^{\mathrm{a}}$ & $17.4^{\mathrm{a}}$ & $7.2^{\mathrm{a}}$ & $2.3^{\mathrm{a}}$ & $3.7^{\mathrm{a}}$ & $6.0^{\mathrm{a}}$ & $11.3^{\mathrm{a}}$ & $22.8^{\mathrm{a}}$ & $20.8^{\mathrm{a}}$ \\
\hline & & $\mathrm{CK}$ & $17.0^{\mathrm{b}}$ & $14.0^{\mathrm{b}}$ & $4.1^{\mathrm{b}}$ & $2.6^{\mathrm{b}}$ & $2.7^{\mathrm{b}}$ & $3.2^{\mathrm{b}}$ & $8.5^{\mathrm{b}}$ & $20.9^{\mathrm{a}}$ & $18.4^{\mathrm{a}}$ \\
\hline & \multirow{3}{*}{25} & M1 & $19.8^{\mathrm{a}}$ & $16.8^{\mathrm{a}}$ & $6.5^{\mathrm{a}}$ & $4.5^{\mathrm{a}}$ & $4.2^{\mathrm{a}}$ & $5.0^{\mathrm{a}}$ & $10.8^{\mathrm{a}}$ & $21.7^{\mathrm{a}}$ & $19.0^{\mathrm{a}}$ \\
\hline & & M2 & $19.5^{\mathrm{a}}$ & $16.7^{\mathrm{a}}$ & $6.2^{\mathrm{a}}$ & $4.3^{\mathrm{a}}$ & $4.1^{\mathrm{a}}$ & $4.7^{\mathrm{a}}$ & $10.5^{\mathrm{a}}$ & $21.5^{\mathrm{a}}$ & $18.8^{\mathrm{a}}$ \\
\hline & & M3 & $19.3^{\mathrm{a}}$ & $16.2^{\mathrm{a}}$ & $6.0^{\mathrm{a}}$ & $4.0^{\mathrm{a}}$ & $3.9^{\mathrm{a}}$ & $4.5^{\mathrm{a}}$ & $10.4^{\mathrm{a}}$ & $21.2^{\mathrm{a}}$ & $18.6^{\mathrm{a}}$ \\
\hline \multirow{8}{*}{ 2013-2014 } & \multirow{5}{*}{5} & $\mathrm{CK}$ & $15.7^{\mathrm{b}}$ & $13.9^{\mathrm{b}}$ & $6.8^{\mathrm{b}}$ & $2.7^{\mathrm{b}}$ & $-1.7^{\mathrm{b}}$ & $-0.2^{\mathrm{b}}$ & $10.7^{b}$ & $14.4^{\mathrm{a}}$ & $16.0^{\mathrm{a}}$ \\
\hline & & M1 & $19.8^{\mathrm{a}}$ & $18.7^{\mathrm{a}}$ & $9.1^{\mathrm{a}}$ & $5.1^{\mathrm{a}}$ & $0.1^{\mathrm{a}}$ & $2.6^{\mathrm{a}}$ & $13.6^{\mathrm{a}}$ & $15.0^{\mathrm{a}}$ & $16.7^{\mathrm{a}}$ \\
\hline & & M2 & $19.3^{\mathrm{a}}$ & $18.4^{\mathrm{a}}$ & $9.2^{\mathrm{a}}$ & $4.8^{\mathrm{a}}$ & $0.0^{\mathrm{a}}$ & $2.3^{\mathrm{a}}$ & $13.4^{\mathrm{a}}$ & $14.8^{\mathrm{a}}$ & $16.3^{\mathrm{a}}$ \\
\hline & & M3 & $19.0^{\mathrm{a}}$ & $18.0^{\mathrm{a}}$ & $8.6^{\mathrm{a}}$ & $4.4^{\mathrm{a}}$ & $-0.2^{\mathrm{a}}$ & $2.0^{\mathrm{a}}$ & $13.3^{\mathrm{a}}$ & $14.6^{\mathrm{a}}$ & $16.2^{\mathrm{a}}$ \\
\hline & & $\mathrm{CK}$ & $13.2^{\mathrm{b}}$ & $12.8^{\mathrm{b}}$ & $4.4^{\mathrm{b}}$ & $3.5^{\mathrm{b}}$ & $0.0^{\mathrm{b}}$ & $0.6^{\mathrm{b}}$ & $9.2^{\mathrm{b}}$ & $12.2^{\mathrm{a}}$ & $13.2^{\mathrm{a}}$ \\
\hline & \multirow{3}{*}{25} & M1 & $15.9^{\mathrm{a}}$ & $15.9^{\mathrm{a}}$ & $6.4^{\mathrm{a}}$ & $4.9^{\mathrm{a}}$ & $1.3^{\mathrm{a}}$ & $1.5^{\mathrm{a}}$ & $11.0^{\mathrm{a}}$ & $12.9^{\mathrm{a}}$ & $13.9^{\mathrm{a}}$ \\
\hline & & M2 & $15.5^{\mathrm{a}}$ & $15.6^{\mathrm{a}}$ & $6.2^{\mathrm{a}}$ & $4.6^{\mathrm{a}}$ & $1.1^{\mathrm{a}}$ & $1.2^{\mathrm{a}}$ & $10.3^{\mathrm{a}}$ & $12.6^{\mathrm{a}}$ & $13.8^{\mathrm{a}}$ \\
\hline & & M3 & $15.4^{\mathrm{a}}$ & $15.7^{\mathrm{a}}$ & $5.9^{\mathrm{a}}$ & $4.4^{\mathrm{a}}$ & $1.0^{\mathrm{a}}$ & $1.0^{\mathrm{a}}$ & $10.4^{\mathrm{a}}$ & $12.4^{\mathrm{a}}$ & $13.5^{\mathrm{a}}$ \\
\hline \multirow{8}{*}{ 2014-2015 } & \multirow{4}{*}{5} & $\mathrm{CK}$ & $17.7^{\mathrm{b}}$ & $12.6^{\mathrm{b}}$ & $6.1^{\mathrm{b}}$ & $1.0^{\mathrm{b}}$ & $1.2^{\mathrm{b}}$ & $7.3^{\mathrm{b}}$ & $11.8^{\mathrm{b}}$ & $15.0^{\mathrm{a}}$ & $20.6^{\mathrm{a}}$ \\
\hline & & M1 & $22.8^{\mathrm{a}}$ & $17.2^{\mathrm{a}}$ & $9.4^{\mathrm{a}}$ & $3.0^{\mathrm{a}}$ & $3.0^{\mathrm{a}}$ & $10.1^{\mathrm{a}}$ & $14.6^{\mathrm{a}}$ & $15.8^{\mathrm{a}}$ & $20.9^{\mathrm{a}}$ \\
\hline & & M2 & $22.4^{\mathrm{a}}$ & $17.0^{\mathrm{a}}$ & $9.0^{\mathrm{a}}$ & $2.7^{\mathrm{a}}$ & $2.8^{\mathrm{a}}$ & $9.9^{\mathrm{a}}$ & $14.5^{\mathrm{a}}$ & $15.6^{\mathrm{a}}$ & $20.5^{\mathrm{a}}$ \\
\hline & & M3 & $21.9^{\mathrm{a}}$ & $16.6^{\mathrm{a}}$ & $8.8^{\mathrm{a}}$ & $2.5^{\mathrm{a}}$ & $2.7^{\mathrm{a}}$ & $9.5^{\mathrm{a}}$ & $14.2^{\mathrm{a}}$ & $15.3^{\mathrm{a}}$ & $20.3^{\mathrm{a}}$ \\
\hline & \multirow{4}{*}{25} & CK & $16.2^{\mathrm{b}}$ & $11.6^{\mathrm{b}}$ & $3.5^{\mathrm{b}}$ & $2.9^{\mathrm{b}}$ & $2.3^{\mathrm{b}}$ & $6.5^{\mathrm{b}}$ & $10.3^{b}$ & $11.7^{\mathrm{a}}$ & $17.2^{\mathrm{a}}$ \\
\hline & & M1 & $19.5^{\mathrm{a}}$ & $14.8^{\mathrm{a}}$ & $5.6^{\mathrm{a}}$ & $5.1^{\mathrm{a}}$ & $3.7^{\mathrm{a}}$ & $8.5^{\mathrm{a}}$ & $12.8^{\mathrm{a}}$ & $12.3^{\mathrm{a}}$ & $17.6^{\mathrm{a}}$ \\
\hline & & M2 & $19.2^{\mathrm{a}}$ & $14.6^{\mathrm{a}}$ & $5.3^{\mathrm{a}}$ & $4.8^{\mathrm{a}}$ & $3.6^{\mathrm{a}}$ & $8.1^{\mathrm{a}}$ & $12.6^{\mathrm{a}}$ & $12.4^{\mathrm{a}}$ & $17.7^{\mathrm{a}}$ \\
\hline & & M3 & $18.8^{\mathrm{a}}$ & $14.3^{\mathrm{a}}$ & $4.9^{\mathrm{a}}$ & $4.6^{\mathrm{a}}$ & $3.3^{\mathrm{a}}$ & $7.9^{\mathrm{a}}$ & $12.3^{\mathrm{a}}$ & $12.1^{\mathrm{a}}$ & $17.3^{\mathrm{a}}$ \\
\hline
\end{tabular}

Note: Different lowercase letters within a column denote significant differences among treatments at the same soil depth in the same planting year at $P<0.05$ level.

At depths of 5 and $25 \mathrm{~cm}$, soil temperatures from September to March next year were significantly higher in M1, M2 and M3 than in control $(P<0.05)$. Soil temperatures were not significantly different between the four treatments in April and May. At depths of 5 and $25 \mathrm{~cm}$, soil temperatures were highest in M1, followed by M2 and M3. For example, soil temperatures at depths of 5 and $25 \mathrm{~cm}$ were respectively $0.2^{\circ} \mathrm{C}-1.1^{\circ} \mathrm{C}$ and $0.2^{\circ} \mathrm{C}-0.7^{\circ} \mathrm{C}$ lower in $\mathrm{M} 3$ than in $\mathrm{M} 1$, and $0.2^{\circ} \mathrm{C}-0.6^{\circ} \mathrm{C}$ and $0.1^{\circ} \mathrm{C}-0.4^{\circ} \mathrm{C}$ lower in $\mathrm{M} 3$ than in $\mathrm{M} 2$. However, significant differences were not found among the three mulching treatments (i.e., M1, M2 and M3).

\subsection{SOC content}

SOC content was significantly influenced by planting and mulching pattern, planting year, soil depth, and their interactions (Table 3). At harvest of winter oilseed rape, the control treatment had 
the highest SOC content in the $0-30 \mathrm{~cm}$ soil layer over all three growing seasons (Table 5). The SOC content did not differ significantly among treatments in any soil layer during the growing season of 2012-2013 or in the 20-30 cm soil layer during the growing season of 2013-2014. In the $0-20 \mathrm{~cm}$ soil layer, SOC content was markedly higher in control than in M1 and M2, during the growing seasons of 2013-2014 and 2014-2015.

At the harvest of 2014-2015 growing season, SOC content in the 0-10 and 10-20 cm soil layers in M3 was $7.3 \%$ and $6.5 \%$ lower than those in control $(P<0.05), 12.1 \%$ and $9.6 \%$ higher than those in M1 $(P<0.05)$, and $8.7 \%$ and $7.4 \%$ higher than those in M2 $(P<0.05)$, respectively. Furthermore, SOC content in the $20-30 \mathrm{~cm}$ soil layer was significantly lower in M1 and M2 than in control.

Table 5 Soil organic carbon (SOC) content at harvest of winter oilseed rape under different planting and mulching treatments during the three growing seasons of 2012-2013, 2013-2014 and 2014-2015

\begin{tabular}{|c|c|c|c|c|c|c|c|c|c|}
\hline \multirow{3}{*}{ Treatment } & \multicolumn{9}{|c|}{ SOC content ( $\mathrm{g} \mathrm{C} / \mathrm{kg}$ soil) } \\
\hline & \multicolumn{3}{|c|}{$2012-2013$} & \multicolumn{3}{|c|}{ 2013-2014 } & \multicolumn{3}{|c|}{ 2014-2015 } \\
\hline & $0-10 \mathrm{~cm}$ & $10-20 \mathrm{~cm}$ & $20-30 \mathrm{~cm}$ & $0-10 \mathrm{~cm}$ & $10-20 \mathrm{~cm}$ & $20-30 \mathrm{~cm}$ & $0-10 \mathrm{~cm}$ & $10-20 \mathrm{~cm}$ & $20-30 \mathrm{~cm}$ \\
\hline Control & $7.28^{\mathrm{a}}$ & $7.41^{\mathrm{a}}$ & $6.95^{\mathrm{a}}$ & $6.97^{\mathrm{a}}$ & $7.27^{\mathrm{a}}$ & $6.83^{\mathrm{a}}$ & $7.15^{\mathrm{a}}$ & $7.18^{\mathrm{a}}$ & $6.76^{\mathrm{a}}$ \\
\hline M1 & $7.03^{\mathrm{a}}$ & $7.09^{\mathrm{a}}$ & $6.68^{\mathrm{a}}$ & $6.41^{\mathrm{b}}$ & $6.75^{\mathrm{b}}$ & $6.52^{\mathrm{a}}$ & $5.91^{\mathrm{c}}$ & $6.12^{\mathrm{c}}$ & $5.99^{\mathrm{b}}$ \\
\hline M2 & $7.12^{\mathrm{a}}$ & $7.15^{\mathrm{a}}$ & $6.76^{\mathrm{a}}$ & $6.53^{\mathrm{b}}$ & $6.86^{\mathrm{b}}$ & $6.65^{\mathrm{a}}$ & $6.10^{\mathrm{c}}$ & $6.25^{\mathrm{c}}$ & $6.08^{\mathrm{b}}$ \\
\hline M3 & $7.20^{\mathrm{a}}$ & $7.28^{\mathrm{a}}$ & $6.89^{\mathrm{a}}$ & $6.71^{\mathrm{ab}}$ & $6.96^{\mathrm{ab}}$ & $6.72^{\mathrm{a}}$ & $6.63^{\mathrm{b}}$ & $6.71^{\mathrm{b}}$ & $6.32^{\mathrm{ab}}$ \\
\hline
\end{tabular}

Note: Different lowercase letters within a column denote significant differences between treatments at $P<0.05$ level.

\subsection{Soil nutrient content}

TN, TP and TK contents were not significantly influenced by planting and mulching pattern, planting year, and their interactions (Table 3). Nitrate-N, AP and AK contents were only significantly affected by planting and mulching pattern. In all three growing seasons, nitrate-N content at harvest of winter oilseed rape was markedly lower in control than in M1, M2 and M3 (Table 6). No significant differences of nitrate-N content were observed among the three mulching treatments during the growing seasons of 2012-2013 and 2013-2014. Nitrate-N content was 7.6\% and 5.8\% higher in M3 than in M1 and M2, respectively, during the growing season of 2014-2015.

$\mathrm{AP}$ and AK contents were significantly higher in M3 than in control and M1 over all growing seasons (with an exception of AP content during the growing season of 2013-2014; Table 6). In all three growing seasons, AP and AK contents were not significantly different between M2 and $\mathrm{M} 3$, although $\mathrm{AP}$ and $\mathrm{AK}$ contents were $2.7 \%-4.3 \%$ and $0.6 \%-3.5 \%$ higher in $\mathrm{M} 3$ than in $\mathrm{M} 2$, respectively.

Table 6 Soil nutrient content in the $0-30 \mathrm{~cm}$ soil layer at harvest of winter oilseed rape under different planting and mulching treatments during the three growing seasons of 2012-2013, 2013-2014 and 2014-2015

\begin{tabular}{|c|c|c|c|c|c|c|c|}
\hline Year & Treatment & $\begin{array}{c}\text { Total N } \\
(\mathrm{g} / \mathrm{kg})\end{array}$ & $\begin{array}{c}\text { Total P } \\
(\mathrm{g} / \mathrm{kg})\end{array}$ & $\begin{array}{c}\text { Total K } \\
(\mathrm{g} / \mathrm{kg})\end{array}$ & $\begin{array}{c}\text { Nitrate-N } \\
(\mathrm{mg} / \mathrm{kg})\end{array}$ & $\begin{array}{c}\text { Available P } \\
(\mathrm{mg} / \mathrm{kg})\end{array}$ & $\begin{array}{c}\text { Available K } \\
(\mathrm{mg} / \mathrm{kg})\end{array}$ \\
\hline \multirow{4}{*}{$2012-2013$} & Control & $0.70^{\mathrm{a}}$ & $0.50^{\mathrm{a}}$ & $10.51^{\mathrm{a}}$ & $22.61^{\mathrm{b}}$ & $10.82^{\mathrm{c}}$ & $122.64^{\mathrm{c}}$ \\
\hline & M1 & $0.72^{\mathrm{a}}$ & $0.51^{\mathrm{a}}$ & $10.85^{\mathrm{a}}$ & $24.96^{\mathrm{a}}$ & $11.90^{\mathrm{b}}$ & $132.50^{\mathrm{b}}$ \\
\hline & M2 & $0.75^{\mathrm{a}}$ & $0.54^{\mathrm{a}}$ & $11.01^{\mathrm{a}}$ & $25.01^{\mathrm{a}}$ & $12.88^{\mathrm{ab}}$ & $140.53^{\mathrm{a}}$ \\
\hline & M3 & $0.77^{\mathrm{a}}$ & $0.55^{\mathrm{a}}$ & $11.30^{\mathrm{a}}$ & $25.51^{\mathrm{a}}$ & $13.30^{\mathrm{a}}$ & $142.64^{\mathrm{a}}$ \\
\hline \multirow{4}{*}{ 2013-2014 } & Control & $0.67^{\mathrm{a}}$ & $0.46^{\mathrm{a}}$ & $10.29^{\mathrm{a}}$ & $18.01^{\mathrm{b}}$ & $10.27^{\mathrm{b}}$ & $118.57^{\mathrm{c}}$ \\
\hline & M1 & $0.68^{\mathrm{a}}$ & $0.48^{\mathrm{a}}$ & $10.54^{\mathrm{a}}$ & $21.69^{\mathrm{a}}$ & $11.24^{\mathrm{a}}$ & $132.25^{\mathrm{b}}$ \\
\hline & M2 & $0.69^{\mathrm{a}}$ & $0.49^{\mathrm{a}}$ & $10.55^{\mathrm{a}}$ & $22.03^{\mathrm{a}}$ & $11.36^{\mathrm{a}}$ & $138.36^{\mathrm{ab}}$ \\
\hline & M3 & $0.72^{\mathrm{a}}$ & $0.50^{\mathrm{a}}$ & $10.57^{\mathrm{a}}$ & $22.12^{\mathrm{a}}$ & $11.85^{\mathrm{a}}$ & $139.21^{\mathrm{a}}$ \\
\hline \multirow{4}{*}{ 2014-2015 } & Control & $0.66^{\mathrm{a}}$ & $0.49^{\mathrm{a}}$ & $10.49^{\mathrm{b}}$ & $20.24^{\mathrm{c}}$ & $10.67^{\mathrm{c}}$ & $125.49^{\mathrm{c}}$ \\
\hline & M1 & $0.68^{\mathrm{a}}$ & $0.51^{\mathrm{a}}$ & $11.36^{\mathrm{a}}$ & $22.69^{b}$ & $11.36^{\mathrm{b}}$ & $140.25^{\mathrm{b}}$ \\
\hline & M2 & $0.70^{\mathrm{a}}$ & $0.52^{\mathrm{a}}$ & $11.38^{\mathrm{a}}$ & $23.09^{\mathrm{b}}$ & $12.25^{\mathrm{a}}$ & $143.26^{\mathrm{ab}}$ \\
\hline & M3 & $0.71^{\mathrm{a}}$ & $0.56^{\mathrm{a}}$ & $11.42^{\mathrm{a}}$ & $24.42^{\mathrm{a}}$ & $12.58^{\mathrm{a}}$ & $148.25^{\mathrm{a}}$ \\
\hline
\end{tabular}

Note: Different lowercase letters within a column denote significant differences between treatments in the same planting year at $P<0.05$ level. 


\subsection{Soil enzymatic activity}

Enzymatic activities of invertase, urease and alkaline phosphatase were significantly affected by planting and mulching pattern, planting year, soil depth, and their interactions (Table 3). Enzymatic activities of invertase, urease and alkaline phosphatase all gradually decreased with increasing soil depth (Fig. 4). Specifically, they were $9.6 \%-20.4 \%, 6.3 \%-17.5 \%$ and $8.9 \%-19.9 \%$ higher in the $0-10 \mathrm{~cm}$ soil layer than in the $10-20 \mathrm{~cm}$ soil layer, and $19.0 \%-81.5 \%$, $8.0 \%-26.6 \%$ and $59.8 \%-77.8 \%$ higher in the $10-20 \mathrm{~cm}$ soil layer than in the $20-30 \mathrm{~cm}$ soil layer, respectively.
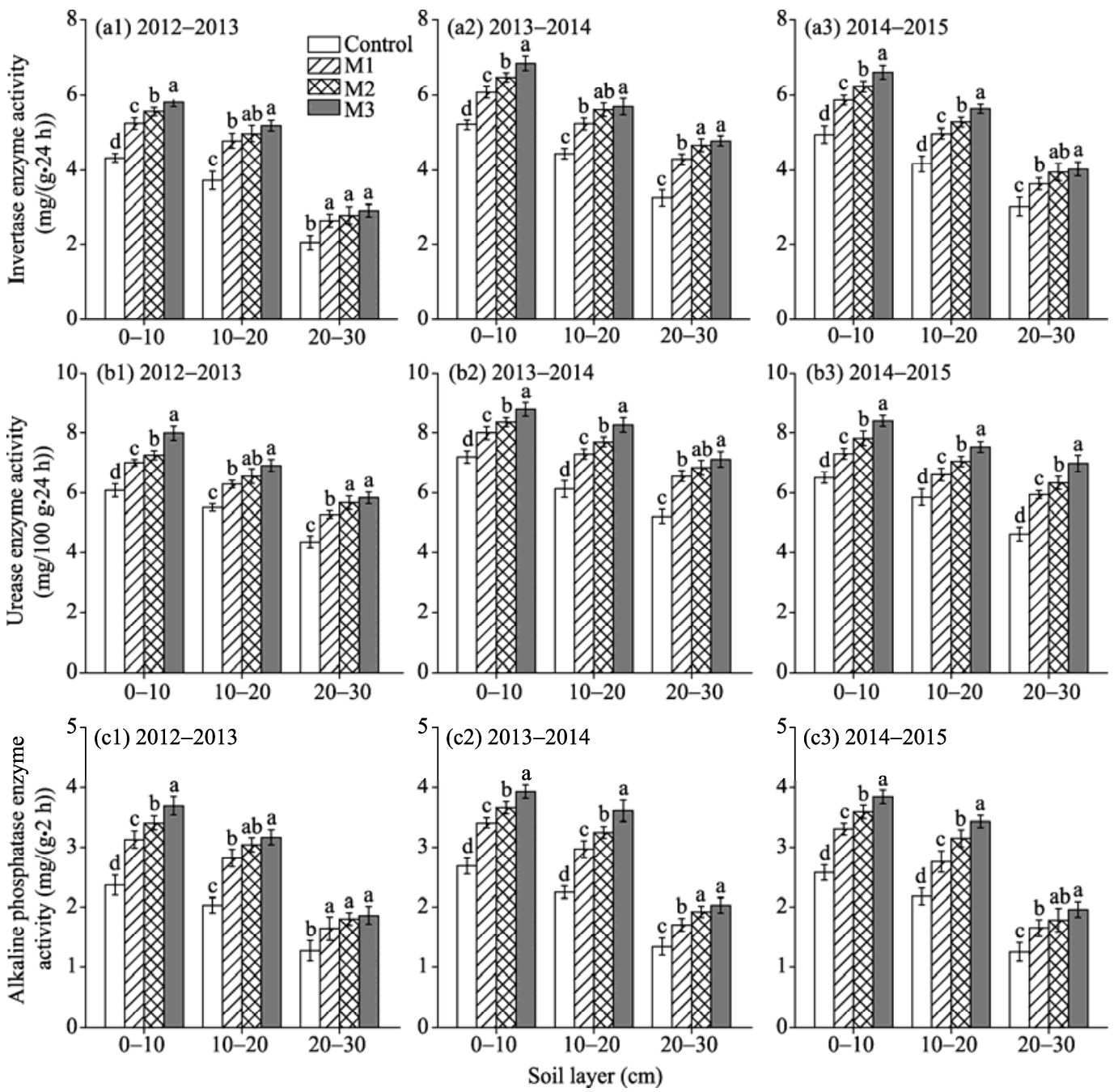

Fig. 4 Soil enzymatic activities in the $0-30 \mathrm{~cm}$ soil layers under different planting and mulching treatments during the three growing seasons of 2012-2013, 2013-2014 and 2014-2015. Bars represent standard deviations. Different lowercase letters denote significant differences between treatments for the same soil layer in the same planting year at $P<0.05$ level.

Invertase enzyme activity was highest in M3 in the three soil layers over all growing seasons (Fig. 4). In the $0-10 \mathrm{~cm}$ soil layer, invertase enzyme activity was $12.1 \%$ and $5.5 \%$ higher than in M3 than in M1 and M2, respectively $(P<0.05)$. Invertase enzyme activity in M2 and M3 did not differ significantly in the 10-20 cm soil layer during the growing seasons of 2012-2013 and 2013-2014.

Urease enzyme activity in the three soil layers was highest in M3 and lowest in control over all three growing seasons (Fig. 4). In the $20-30 \mathrm{~cm}$ soil layer, urease enzyme activity was 
$33.7 \%-51.1 \%$ and $8.5 \%-17.5 \%$ greater in $\mathrm{M} 3$ than in $\mathrm{CK}$ and $\mathrm{M} 1$, respectively $(P<0.05)$. There was no significant difference of urease enzyme activity between M2 and M3 in the 10-20 and $20-30 \mathrm{~cm}$ soil layers during the growing season of 2012-2013 and in the $20-30 \mathrm{~cm}$ soil layer during the growing season of 2013-2014.

Alkaline phosphatase enzyme activity was also highest in M3 and lowest in control in all soil layers over the three growing seasons (Fig. 4). In the $0-10 \mathrm{~cm}$ soil layer, alkaline phosphatase enzyme activity was $50.0 \%, 16.3 \%$ and $7.5 \%$ higher in M3 than in control, M1 and M2, respectively; in the 10-20 cm soil layer, alkaline phosphatase enzyme activity was $58.0 \%, 19.4 \%$ and 8.2\% higher in M3 than in control, M1 and M2, respectively; and in the 20-30 cm soil layer, alkaline phosphatase enzyme activity was $51.6 \%, 17.2$ and $6.4 \%$ higher in M3 than in control, M1 and M2, respectively. In the $20-30 \mathrm{~cm}$ soil layer, no significant differences of alkaline phosphatase enzyme activity were found between M2 and M3 over all three growing seasons.

\section{Discussion}

\subsection{Soil moisture and temperature}

Previous studies have demonstrated that film mulching can effectively increase soil moisture in the root zone (Wang et al., 2009; Gan et al., 2013; Liu et al., 2014; Qin et al., 2014). Our study obtained similar results that soil moisture in the $0-30 \mathrm{~cm}$ soil layer was higher in M1, M2 and M3 (mulching treatments) than in control (no mulching treatment). Among the three mulching treatments, soil moisture was higher in M2 and M3 (ridge-furrow planting with film mulching) than in M1. This may be due to the high utilization efficiency of light rains $(<5 \mathrm{~mm})$ in M2 and M3 (Li et al., 2000). Compared with M2, the soil moisture was much higher in M3 where an extra ridge existed, which increased the rainfall harvesting efficiency (Gu et al., 2016).

At depths of 5 and $25 \mathrm{~cm}$, soil temperatures were $1.4^{\circ} \mathrm{C}-5.1^{\circ} \mathrm{C}$ and $0.9^{\circ} \mathrm{C}-3.3^{\circ} \mathrm{C}$ higher in mulching treatments than in control treatment, respectively, during the early growing periods. However, soil temperatures were similar in the four treatments during the late growing periods. Our results agreed with a previous study which demonstrated that mulching can increase soil temperature during the early growing periods (Wang et al., 2015). These results are likely due to the underdeveloped plant canopy during the early stages of crop development. Solar energy and its heat are trapped when they hit the plastic mulch, in turn warming the topsoil. During the later growing stages, plant-covered plots increase soil temperatures less than uncovered plots, because plants flourish during these periods and block more solar energy (Zhou et al., 2009). Soil temperatures at depths of 5 and $25 \mathrm{~cm}$ were slightly lower in M3 than in M1 and M2, perhaps as a result of higher soil moisture in M3. Additionally, the plant canopy cover was larger in M3 than in M1 and M2.

The soil temperature variation was greater at $5 \mathrm{~cm}$ soil depth than at $25 \mathrm{~cm}$ soil depth. Therefore, we infer that film mulching affects soil temperatures mainly in the shallow soil layer. This can be attributed to the high absorption and reflection of solar energy by the film and the high temperature buffering capacity of the deep soil layer.

\subsection{Seed yield}

The three mulching treatments consistently produced higher seed yield of winter oilseed rape than the control treatment over all three growing seasons. Our results are consistent with previous studies correlating mulching treatments and seed yields of maize (Gao et al., 2014) and potato (Qin et al., 2014). The significantly highest seed yield in M3 is likely because of the highest soil moisture in the top $0-30 \mathrm{~cm}$ soil layers. The seed yield of winter oilseed rape was higher in 2013-2014 and 2014-2015 than in 2012-2013, probably due to the abundant precipitation during critical growth stages, especially throughout the flowering and pod-filling stages during the growing seasons of 2013-2014 and 2014-2015.

\subsection{SOC content}

SOC content is of vital importance to improve nutrient availability and maintain soil nutrient 
content (Lal, 2004). Additionally, it has been shown that SOC losses can decrease soil fertility (Lumbanraja et al., 1998). In our study, SOC content in the 0-20 cm soil layer did not differ significantly among the four treatments at the end of 2012-2013 growing season, but it was significantly lower in M1 and M2 than in M3 at the end of 2013-2014 growing season, indicating that film mulching led to a more rapid conversion of SOC by ensuring a suitable micro-ecological environment for microorganisms ( $\mathrm{Li}$ et al., 2004; Mbah et al., 2010). In the 20-30 cm soil layer, SOC content did not differ markedly between M1, M2 and control in the first and second growing seasons (i.e., 2012-2013 and 2013-2014), indicating that the influence of film mulching on SOC content was minimal in the deep soil layers. During the third growing season (2014-2015), SOC content in M3 was significantly lower than that in control and significantly higher than those in M1 and M2 in the top 0-20 cm soil layers $(P<0.05)$, perhaps because soil temperature was low in $\mathrm{M} 3$, thus decreasing SOC decomposition rate.

\subsection{Soil nutrient content}

Soil nutrient content is closely associated with the healthy growth and final yield of crops. Previous researchers have found that film mulching significantly affects the content and distribution of nitrate- $\mathrm{N}$, and that the nitrate- $\mathrm{N}$ content is significantly increased in the top soil layers in mulching treatments (Wang et al., 2015; Zhou et al., 2016). In this study, we obtained similar results that the nitrate- $\mathrm{N}$ content in the top $0-30 \mathrm{~cm}$ soil layers was $10.4 \%-22.8 \%$ greater in mulching treatments than in control treatment $(P<0.05)$.

In this study, soil TN, TP, TK, AP and AK contents were always higher in mulching treatments than in control treatment. This is likely because the high soil temperature and water content promoted the decomposition and transformation of organic matter in the soil (Mbah et al., 2010). Furthermore, among the three mulching treatments, the TN, TP, TK, nitrate-N, AP and AK contents were always highest in M3, perhaps due to the increased soil moisture accelerated the transfer and diffusion of nutrients (Zhou et al., 2016). It should be noted that we also found that film mulching did not significantly affect TN, TP and TK contents, but markedly increased nitrate-N, AP and AK contents. The reason might be that nitrate- N, AP and AK contents are more susceptible to the changes of soil temperature, moisture, and even microorganism abundance and enzymatic activities caused by film mulching.

\subsection{Soil enzymatic activity}

Soil biochemical processes are largely influenced by soil enzymes. Monitoring soil enzymatic activity can be used to develop indices reflecting the extent of soil recovery in particular ecosystems (Araújo et al., 2013). Siczek and Frąc (2012) found that soil enzymatic activities were higher in mulching treatment than in non-mulching treatment, similar to our results. Enzymatic activities of invertase, urease and alkaline phosphatase in the top $0-30 \mathrm{~cm}$ soil layers were always significantly higher in mulching treatments than in control treatment. This could be partially because of the higher water availability resulting from decreased evaporation in mulching treatments. A'Bear et al. (2014) also observed that soil enzymatic activities were higher in wet soils than in dry soils.

Among the three mulching treatments (M1, M2 and M3), enzymatic activities of invertase, urease and alkaline phosphatase in the top $0-30 \mathrm{~cm}$ soil layers were all greatest in $\mathrm{M} 3$. In our study, we found that soil moisture in the top $0-30 \mathrm{~cm}$ soil layers was always higher in $\mathrm{M} 3$ than M1 and M2. The reason that soil enzymatic activity is linearly correlated with soil water content (López et al., 2014) may explain the higher enzymatic activities in M3.

\section{Conclusions}

Film mulching significantly improved soil moisture, temperature, contents of nitrate- $\mathrm{N}$, AP and AK, enzymatic activities, and seed yield of winter oilseed rape in all three growing seasons of 2012-2013, 2013-2014 and 2014-2015. However, the SOC content in the three film mulching treatments (M1, M2 and M3) decreased significantly during the growing seasons of 2013-2014 
and 2014-2015 compared with that in control treatment. Among the three film mulching treatments, seed yield, SOC content, soil nutrient contents, and soil enzymatic activities were highest in the mulching treatment with ridge-furrow planting on continuous ridges. Therefore, we advocate this planting and mulching pattern for sustainably improving the seed yield of winter oilseed rape and preserving soil fertility in the semi-arid area of Northwest China.

\section{Acknowledgements}

This research was supported by the Special Fund for Agro-scientific Research in the Public Interest, China (201503125, 201503105) and the National High Technology Research and Development Program of China (2011AA100504).

\section{References}

A'Bear A D, Jones T H, Kandeler E, et al. 2014. Interactive effects of temperature and soil moisture on fungal-mediated wood decomposition and extracellular enzyme activity. Soil Biology and Biochemistry, 70: 151-158.

Araújo A S F, Cesarz S, Leite L F C, et al. 2013. Soil microbial properties and temporal stability in degraded and restored lands of Northeast Brazil. Soil Biology and Biochemistry, 66: 175-181.

Cai X M, Ringler C. 2007. Balancing agricultural and environmental water needs in China: alternative scenarios and policy options. Water Policy, 9(Suppl.): 95-108.

Dalin C, Qiu H G, Hanasaki N, et al. 2015. Balancing water resource conservation and food security in China. Proceedings of the National Academy of Sciences of the United States of America, 112(15): 4588-4593.

Gan Y T, Siddique K H M, Turner N C, et al. 2013. Chapter seven - ridge-furrow mulching systems-an innovative technique for boosting crop productivity in semiarid rain-fed environments. Advances in Agronomy, 118: 429-476.

Gao Y H, Xie Y P, Jiang H Y, et al. 2014. Soil water status and root distribution across the rooting zone in maize with plastic film mulching. Field Crops Research, 156: 40-47.

Griffin G, Jokela W, Ross D, et al. 2009. Recommended soil nitrate tests. In: Sims J T, Wolf A M. Recommended Soil Testing Procedures for the Northeastern United States ( $3^{\text {rd }}$ ed.). Newark, DE: Northeastern Regional Publication, 27-38.

Gu X B, Li Y N, Du Y D. 2016. Continuous ridges with film mulching improve soil water content, root growth, seed yield and water use efficiency of winter oilseed rape. Industrial Crops and Products, 85: 139-148.

Gu X B, Li Y N, Du Y D. 2017. Biodegradable film mulching improves soil temperature, moisture and seed yield of winter oilseed rape (Brassica napus L.). Soil and Tillage Research, 171: 42-50.

Huang Q Q. 2014. Impact evaluation of the irrigation management reform in northern China. Water Resources Research, 50(5): $4323-4340$.

Jiao X G, Gao C S, Lü G H, et al. 2011. Effect of long-term fertilization on soil enzyme activities under different hydrothermal conditions in Northeast China. Agricultural Sciences in China, 10(3): 412-422.

Jin K, Sleutel S, Buchan D, et al. 2009. Changes of soil enzyme activities under different tillage practices in the Chinese Loess Plateau. Soil \& Tillage Research, 104(1): 115-120.

Karami A, Homaee M, Afzalinia S, et al. 2012. Organic resource management: impacts on soil aggregate stability and other soil physico-chemical properties. Agriculture, Ecosystems \& Environment, 148: 22-28.

Kou J T, Shi S L, Zhou W H, et al. 2011. Soil nutrient in two-year alfalfa field on condition of film-mulching rainfall harvesting cultivation. Acta Prataculturae Sinica, 20(5): 207-216. (in Chinese)

Kussainova M, Durmuş M, Erkoçak A, et al. 2013. Soil dehydrogenase activity of natural macro aggregates in a toposequence of forest soil. Eurasian Soil Science, 2(1): 69-75.

Lal R. 2004. Soil carbon sequestration impacts on global climate change and food security. Science, 304(5677): $1623-1627$.

Li F M, Song Q H, Jjemba P K, et al. 2004. Dynamics of soil microbial biomass C and soil fertility in cropland mulched with plastic film in a semiarid agro-ecosystem. Soil Biology and Biochemistry, 36(11): 1893-1902.

Li X Y, Gong J D, Wei X H. 2000. In-situ rainwater harvesting and gravel mulch combination for corn production in the dry semi-arid region of China. Journal of Arid Environments, 46(4): 371-382.

Liu X E, Li X G, Hai L, et al. 2014. How efficient is film fully-mulched ridge-furrow cropping to conserve rainfall in soil at a rainfed site? Field Crops Research, 169: 107-115.

López R, Burgos P, Hermoso J M, et al. 2014. Long term changes in soil properties and enzyme activities after almond shell mulching in avocado organic production. Soil and Tillage Research, 143: 155-163.

Lumbanraja J, Syam T, Nishide H, et al. 1998. Deterioration of soil fertility by land use changes in south Sumatra, Indonesia: 
from 1970 to 1990. Hydrological Processes, 12(13-14): 2003-2013.

Mbah C N, Nwite J N, Njoku C, et al. 2010. Physical properties of an ultisol under plastic film and no-mulches and their effect on the yield of maize. World Journal of Agricultural Sciences, 6(2): 160-165.

Qin S H, Zhang J L, Dai H L, et al. 2014. Effect of ridge-furrow and plastic-mulching planting patterns on yield formation and water movement of potato in a semi-arid area. Agricultural Water Management, 131: 87-94.

Siczek A, Frąc M. 2012. Soil microbial activity as influenced by compaction and straw mulching. International Agrophysics, 26(1): 65-69.

Tian Y, Su D R, Li F M, et al. 2003. Effect of rainwater harvesting with ridge and furrow on yield of potato in semiarid areas. Field Crops Research, 84(3): 385-391.

Wang X J, Jia Z K, Liang L Y, et al. 2016. Impacts of manure application on soil environment, rainfall use efficiency and crop biomass under dryland farming. Scientific Reports, 6: 20994.

Wang X K, Li Z B, Xing Y Y. 2015. Effects of mulching and nitrogen on soil temperature, water content, nitrate-N content and maize yield in the Loess Plateau of China. Agricultural Water Management, 161: 53-64.

Wang Y J, Xie Z K, Malhi S S, et al. 2009. Effects of rainfall harvesting and mulching technologies on water use efficiency and crop yield in the semi-arid Loess Plateau, China. Agricultural Water Management, 96(3): 374-382.

Yao X H, Min H, Lü Z G, et al. 2006. Influence of acetamiprid on soil enzymatic activities and respiration. European Journal of Soil Biology, 42(2): 120-126.

Zhou C M, Li Y N, Gu X B, et al. 2016. Effects of biodegradable film mulching planting patterns on soil nutrient and nitrogen use efficiency of summer maize. Transactions of the Chinese Society for Agricultural Machinery, 47(2): 133-142, 112. (in Chinese)

Zhou L M, Li F M, Jin S L, et al. 2009. How two ridges and the furrow mulched with plastic film affect soil water, soil temperature and yield of maize on the semiarid Loess Plateau of China. Field Crops Research, 113(1): 41-47. 